\title{
HOW SMALL BUSINESS COMPETES FOR FUNDS
}

\author{
Donald WrLhelm, JR.*
}

\section{The Problem}

Everybody agrees that small business should have adequate loan and equity capital on reasonable terms and conditions. But disagreement arises as to whether small business already has such access and, if it does not, how it can get it.

For example, a study ${ }^{1}$ published in 1939 concludes as follows:

The needs of small borrowers in the fields of business and personal finance alike are being well taken care of by the commercial banks.

Meanwhile an investigation in $1935^{2}$ had found that

... there exists a genuine unsatisfied demand for credit on the part of solvent borrowers, many of whom could make economically sound use of working capital.

And a study ${ }^{3}$ conducted in $x 93^{8}$ under the auspices of the Department of Commerce revealed that of a sample of 600 firms chosen because of their relatively high commercial ratings, 75 percent indicated that they were unable to obtain permanent capital in the regular markets, 40 percent indicated that they had no source of longterm credit, and 45 percent indicated difficulty in obtaining funds for working capital purposes.

The testimony of small businessmen themselves, and of their trade association representatives, often adds to the general confusion. For example, of the witnesses who testified in hearings held by the Ohio Small Business Commission in the first half of 1944 ,

"Some ... were of the opinion that the Government should make loans or guarantee loans to small business, but others were equally insistent that they wanted no Government help. Of 24 firms questioned in one town, I8 said that they do not have access to the same sources of capital as big business has. ..."

*A.B., 1938, Yale College; graduate work, Yale University and Graduate School of Public Administration, Harvard University. Division of Small Business, Department of Commerce; previously in Statistics Division, Office of Production Research and Development, and Office of the Chairman, War Production Board.

${ }^{1}$ EDWARds, How Banks LENd (Research Council of the American Bankers Association, Ncw York, 1939) I0.

${ }^{2}$ Hardy and Viner, Report on the Avaliability of Bank Credit in the Seventit Federal RzSERVE DisTRICr (Washington, 1935) vi.

${ }^{3}$ For a summary of this study see Stoddard, Small Bussiness Wants Capital (1940) 18 Harv. Bus. REv, 265, 271-2.

- Whaley, Business Worries Not All Government (Jan. 1945) Domestic Comanerce I4. 
And it is reported" that bankers who testified at the same hearings "as a rule deplored not only Government regulations and restrictions on loans but also competition from finance companies and cooperative credit associations."

How can methodical studies on the small business credit problem reach such divergent conclusions? And how can the "hard-boiled" testimony of small businessmen themselves, and of their bankers and trade association people, lead to the same contradictions? The following quotation perhaps contains a clue:

"The banks of the country . . . are going to make sure that enterprise has adequate credit for every legitimate use and has that credit in the form best adapted to each particular business."

The vagueness of the concepts "adequate credit," "legitimate use," and "the form best adapted to each particular business" is at once apparent. Since this quotation is taken from a press release, it cannot properly be censured for failing to define its terminology carefully; but the concepts employed in the quotation are all too frequently used in more or less scholarly discussions of the small business credit and capital problem. Nor is this always a matter of mere carelessness, for it is actually no easy task to define such terms. For example, is small business access to short-term credit "adequate" if prevailing rates and collateral requirements are well above those for the same type of loans made to large businesses? Some would argue yes, because loans to small concerns are more risky and cost more to service; others would argue no, on the grounds that differences in risks and in costs, though real, are not great enough to justify the prevailing differentials, or on the grounds that the situation should be equalized, arbitrarily if necessary, because it competitively handicaps small business.

It seems evident, therefore, that if the private and governmental sources of funds are to be usefully analyzed and evaluated from the point of view of small business needs, improved criteria are necessary. The following criteria, though by no means perfect, are proposed as a test for each of the sources of credit and capital:

I. What proportion of the total loans which this source makes goes to small business?

2. How do its rates to large borrowers compare with its rates to small borrowers? How do the accommodations this source offers small and large borrowers compare in other respects?

3. If large borrowers generally obtain from some other source the type of money which small borrowers obtain from this source, what are the comparative rates and other conditions?

Notice that each of these criteria is relative rather than absolute, and that it is relative in terms of small vis-à-vis large business. This is justifiable because most of the credit and capital problems of small business are not absolute problems. They are problems which are acute primarily because, in this country today, small

Ibid.

-American Bankers Association, Post-War Small Business Credit Commission (New York), press release, October 16, 1944, quoting Mr. Robert W. Hanes, Chairman of the Commission. 
businesses compete with large businesses not only in designing, producing, and marketing products and services, but also in obtaining the funds with which to operate and expand.

\section{Private Sources of Small Business Credit and Capital: Commercial Banks and Trust Companies}

\section{The Commercial Banks}

The commercial banks have traditionally been the major source of business loan capital in this country. They are still by far the largest single source. For example, a study ${ }^{7}$ made in 1935 of a sample of small manufacturers indicated that well over. 80 percent of the borrowing firms normally depended upon banks ${ }^{8}$ for working capital purposes, and some 18 percent for long-term capital. ${ }^{\circ}$ Since the commercial banks are being treated in another article in this symposium, the present paper will attempt only a brief summary and evaluation of them as a source of small business funds.

As of June 30, 1944, total outstanding commercial bank loans amounted to some $\$ 2 x$ billion.10 Even in a pre-war year like 1937, they stood (on June 30) at over \$17 billion.11 Unfortunately, there are no satisfáctory quantitative data, either by type of loan, type of borrower, or type of accommodation by type of borrower, as to how this huge volume was broken down. Lack of available over-all information on its business lending activities is in fact one of the most notable characteristics of our commercial banking system as it exists today.

In the field of short-term commercial loans, the situation is clouded not only by a startling lack of exact information, but also by virtue of the fact that demand and short term loans often become intermediate or long-term credits before they are fully repaid. This is illustrated by one of several studies ${ }^{12}$ of the lending operations of banks in a number of Pennsylvania and Ohio industrial communities. Business loans at five sampled banks were classified as roughly 24 percent demand loans, $7^{\mathrm{x}}$ percent short-term loans, 3 percent intermediate-term loans, and 2 percent long-term loans. ${ }^{13}$ In terms of elapsed time before the loan or its extension was repayed, however, $4^{6}$ percent of the loans were of short term, 20 percent of intermediate term, and $3^{\mathrm{r}}$ percent turned out to be of long term. The loans having a

${ }^{7}$ U. S. Dep't of Comm., Survey of Reports of Credit \& Capital. Difficulties (1935) 65.

${ }^{8}$ This figure may, however, include industrial banks.

The reliance of these firms on banks for long-term credit requirements appears to indicate that they resorted to using renewable notes to provide long-term money.

${ }^{10}$ (Tan. 1945) 3 I FeD. Res Bull. 48 (table).

${ }^{11} \mathrm{~A}$ substantial proportion of these outstandings were, of course, in the hands of intermediate credit agencies such as factors and sales finance companies.

${ }^{12}$ MCKeE, C. W.: (I) Economic and Business Activity in the Shenango and Mahoning Valleys; (2) Use aNd Users of Bank Credit in Industrial Communities; (3) Size, Security, añd Interest Rates on Bank Loans in Industrial Comaunities; and (4) Maturities, Renewals, and Turnover op Bank Lonns in Industriat Communities (American Economic and Business Foundation, Inc., New Wilmington, $\mathrm{Pa}$., I94I).

${ }^{23}$ McKee, C. W., Maturities, Renewals, and Turnover of Bank Loans in Industrial CommuniTIES, supra note 12, Schedules 3 and 15 . 
long elapsed credit term were, incidentally, on the average larger than those having a short elapsed term. The sampled banks were in the country bank class; city banks are probably on the whole stricter in holding to stated maturities. And in any event short-term renewable loans are recognized as being an unsatisfactory form of intermediate credit, both because they are expensive when used for this purpose (thus leading to high fixed charges) and because they contain an element of uncertainty which makes sound business planning difficult.

Short-term commercial bank loans can be classified in any of a number of ways, for example according to maturity (demand loans and time loans), form (secured or unsecured), class of borrower (loans to customers of different sizes, loans to banks, etc.), purpose, etc. ${ }^{14}$ In practice some of the more common types are socalled "character" loans, loans under lines of credit, loans secured by warehouse or field warehouse receipts, short-term equipment loans secured by the purchased equipment, and miscellaneous other short-term business loans varying mainly as to type of collateral involved.

In the McKee study already referred to, unsecured "character" loans were found to be virtually non-existent in the industrial areas surveyed. Collateral-free "character" loans have in fact become more and more limited to large enterprises of well-recognized stability. Small concerns have likewise experienced increasing difficulty in securing lines of credit.

Not only collateral requirements but also interest rates tend to weigh more heavily on small companies than on large. Though here again the data are sparse, studies by the Board of Governors of the Federal Reserve system, covering a large representative group of member banks, indicate that borrowers with small assets pay, for short-term commercial loans, interest rates averaging over three times as high as those paid by borrowers in the group having the largest assets. ${ }^{15}$ The discrepancy is further accentuated by the practices, which weigh relatively more heavily on the smaller borrower, of discounting interest in advance and requiring a minimum average balance. ${ }^{16}$

In addition to making these conventional types of short-term loans, many commercial banks have recently become active in accounts receivable financing. It is estimated that in I94I the commercial banks advanced over one-third of the $\$ 2.6$ billion total volume of receivables financing, ${ }^{17}$ and that one out of every four commercial banks was active in receivables financing in that year. ${ }^{18}$ Small manufacturers, wholesalers, retailers, and service concerns make wide use of bank loans

\footnotetext{
${ }^{14}$ Cf. Foster and Rodgers, Editors, Money and Banking (Prentice-Hall, New York, 1940), 248-263.

10 (Nov. 1942) 28 Fed. Res. Bull. iogi. Also Weissman, Small Business and Venture Capital (New York, Harper, 1945) 34-35.

10 Thus, if $\$ \mathrm{I}, 000$ is borrowed for one year at a stated rate of 6 percent, with interest (i.e. $\$ 60$ ) deducted in advance, and the borrower is required to maintain an average deposit balance of 20 percent, or $\$ 200$, he is paying $\$ 60$ for the use of $\$ 740$-an effective rate of 8.I I percent.

${ }_{17}$ The remainder was supplied by factors and commercial finance companies.

${ }^{18}$ Saulnier and Jacobx, Accounts Receivable Financing (National Bureau of Economic Research, New York, r943) 4 .
} 
secured by the pledge of accounts or notes receivable. Banks make such loans on either a notification basis (where the bank informs all affected debtors of the transaction and secures payment directly from them) or a non-notification basis. Interest rates average around 5 percent or 6 percent, although separate service charges often increase the effective rate to 7 percent or 8 percent. $^{10}$ Maturity periods are generally not longer than 60 days, although the note is often renewed.

The banks have in many cases also expanded their installment loan activities to handle small business loans as well as loans to individual consumers. Such loans generally run for a year or less. They are usually for from $\$$ roo or less to $\$ 1,000$, though some of them go up to $\$ 2,000$ or $\$ 3,000$. The small businessmen's signature, perhaps plus that of his wife or business associate, will usually get him an installment loan; or he may be required to put up his automobile or offer one of the more usual types of collateral such as cash value of life insurance, mortgages on real estate or plant, or accounts or notes receivable. The loan is generally repaid in monthly installments. Interest rates on bank installment loans are high, commonly ranging from 7 percent to as much as 20 percent or in some cases more.

To satisfy intermediate credit requirements the banks are increasingly making term loans. Though they are akin to the older debenture, term loans as such first became common in the r $930^{\circ}$ s. A term loan is definable as a business loan that is repayable, according to prior agreement between lender and borrower, after a period of more than one year. ${ }^{20}$ Term loan maturity periods average around 5 years but often run to to or 15 years. Term loans are frequently unsecured when made to large firms, but less often when made to small concerns. Term loan contracts usually include specific provisions for repayment out of earnings. Interest rates on commercial bank term loans are in striking inverse relation to the size of the loan. While I percent or 2 percent is not an unusual rate on large term loans, from 5 percent to 7 percent is commonly asked on small term loans. ${ }^{21}$

$\mathrm{Up}$ to the present, term loans made by banks and insurance companies have been mainly to large or medium-sized companies-generally to companies with assets of over a million dollars. Large companies are more and more using term loans instead of short-term renewable loans, and instead of public security issues. The American Bankers Association as well as certain individual banks have recently announced programs which avowedly will increase term lending to small business. During the period I934-4I, the average asset size of business firm securing term loans from commercial banks apparently tended to increase slightly rather than to decrease. $^{22}$

197 . at $134-5$.

${ }^{20} \mathrm{Cf}$. Jacoby and Saulnier, Term Lending to Business (National Bureau of Economic Rescarch, New York, 1942) $\mathrm{Ch}$. I. The definition of a term loan may also well include an upper stated maturity limit to distinguish it from long-term credits. Fifteen years (i.e., under 16 years) makes a good arbitrary ceiling. See id. at 56 .

${ }_{21}$ Id. at Chapter 6.

${ }^{22}$ Id. at 68 . C $f$. also Post-War Smatl Business Credit Commission: Purposes, Organization, Methiods of Operation (American Bankers Association, New York, undated), p. r: "By 1940 . . . some 3,000 banks had two and a half billion in term loans outstanding. For the most part, these were the larger banks and larger loans, averaging about $\$ 600,000$ each." 
Trust Companies and Bank Trust Departments. ${ }^{23}$ Trust companies and bank trust departments are a minor source of short and long-term business funds. For example, in the Commerce study previously referred to ${ }^{24}$ approximately I percent of the replying firms used trust companies as a source of working capital. ${ }^{25}$ The conditions of such loans depend entirely upon the stipulations of the particular trust plus the discretion of trust officers in acting under the trust.

Credit Groups. The correspondent bank relationship, under which larger banks help smaller banks to make loans and render other services they cannot easily handle on their own, has for many years been characteristic of commercial banking in this country. Although in some cases the correspondent relationship has made small banks subservient to large ones, on the whole the system has probably been advantageous to large and small banks and to the business community generally.

Recently, the Post-War Small Business Credit Commission of the American Bankers Association has carried this concept a step further by sponsoring the formation of bank credit groups. ${ }^{26}$ Set up on an area basis, such groups are intended to help banks band together to meet credit needs which they cannot handle individually or on a correspondence basis. Extended discussion of this topic is omitted from this article since it is fully discussed elsewhere in this symposium. ${ }^{2 t}$

Conclusion. The field of commercial banking is plagued by an extreme scarcity of reliable data on the size and type of business loans made, the rates and other conditions set on such loans, and the size and type of business receiving them. Application of the three tests mentioned in Section I nevertheless suggests the following conclusions:

Both small and large businesses still rely heavily on the commercial banks for funds. Yet the range of bank loans available to small concerns is much more limited than those available to their large competitors. Banks provide large business with intermediate credit through term loans, including extended equipment loans, and, in effect, through "continuous" lines of credit. Small firms, on the other hand, are in general confined to short-term loans which, even where renewable, are recognized as an unsatisfactory and expensive source of intermediate credit.

On short-term loans the rates to small borrowers are almost invariably higherfrequently three times or more higher-than the rates to large borrowers; and small borrowers, unlike large ones, are generally required to furnish collateral. Rate differentials are further increased by virtue of the fact that small borrowers must often resort to short-term loans for long-term purposes. Moreover, the practice of

\footnotetext{
${ }^{23}$ Mutual savings banks are not discussed in this paper because, while they hold investment portfolios and make mortgage loans, they are in general prohibited by law from making other types of business loans.

${ }^{34}$ U. S. DeP'r of CoMm., op. cit. supra note 7, at 66 .

${ }^{26} \mathrm{It}$ is possible, however, that some firms mentioning trust companies were using the banking departments of trust companies.

${ }^{30}$ The ABA prefers the term "groups," as applied to this program, rather than "pools," since the funds, though they are considered to constitute a "credit reservoir" for each area, are not actually pooled in advance.

${ }^{27}$ Drew, The Role of the Commercial Bank, infra p. $3^{86}$.
} 
deducting interest in advance and the common requirement of a minimum balance tends to weigh more heavily on small borrowers than on large.

The fact that large concerns enjoy greater access to certain other sources of funds (described below) still further increases their competitive advantage over small concerns which rely on bank borrowing.

Trust companies and bank trust departments are at best a minor source of business funds.

It is too early to draw conclusions on the effect of the bank credit group program on the availability of small business loan funds. So far there appears to be no evidence that it will reduce the differential between large and small companies; nor has this reduction even been specifically announced as one of the objectives of the program.

\section{Other Private Sources of Funds}

In addition to commercial banks and trust companies, small business relies to greater or less extent on a number of other private sources of funds. These other sources include industrial banking companies, small loan companies, factors, insurance companies, commercial paper houses, equipment manufacturers and other suppliers, trade credit, private venture capital, the capital markets, parent companies, and private industrial development groups.

Industrial Banking Companies. Some industrial banks to all intents and purposes resemble the traditional commercial bank, while others resemble small loan companies; yet the industrial banks are really in a group by themselves. Though precise definition is difficult, an industrial banking company may be described as any bank that specializes in consumer installment loans and gets at least part of its working capital from customer deposits, the sale of small-denomination "investment certificates," or both. ${ }^{28}$ Morris Plan banks are typical of industrial banks. Total credit outstandings of all industrial banking companies as of the end of 1938 are estimated as roughly $\$ 250$ million. ${ }^{20}$

The term "industrial bank," though somewhat of a misnomer, was originally coined because of the early emphasis of such banks on consumer loans to industrial workers. The industrial banks have continued their emphasis on reaching "the man in the street," ${ }^{30}$ but the number of business loans made by such banks has been increasing in recent years. It is estimated that in $193^{8}$, for example, some 12 percent of the outstanding loans of insured industrial banks were commercial and industrial loans. ${ }^{31}$ Moreover many of the personal loans made to individuals are for business purposes.

Industrial bank loans range from as low as $\$ 50$ to as much as $\$ 10,000$, depending

${ }^{28}$ Cf. Saulnier, Industrial Banking Companies and Their Credit Practices (Nat'l Bureau of Economic Research, 1940) 12-14.

${ }^{20}$ SAULNIER, id. at 27.

${ }^{30}$ See, for example, Boushall, Seven League Boots for Business (Oct. x944) Banking 29 (President of the Morris Plan Bank of Richmond).

${ }^{31}$ SaULinier, op. cit. sitpra note 28 , at 78 . 
among other things on the law in the particular state. For example, in Arizona, Pennsylvania, and Wisconsin, cash loans up to $\$ \mathrm{r}, 000$ are permissible; in Kentucky, $\$ 2,000$; in Colorado and Rhode Island, $\$ 5,000$. In some cases (for example, in the District of Columbia, which restricts such loans to $\$ 200$ ), industrial banking companies operate under regular bank charters, and so are able to lend much larger amounts. The length of time for which loans may legally be made also varies from state to state. Typically it is one year or two years. Some states have no legal limitation.

The rates industrial banks may charge are regulated by law in many states; but competition with banks and small loan companies often brings the rates to well below the legal maximum. Unlike the personal finance company, which usually levies its charge as a specified rate per month on unpaid principal balance, the industrial banking company generally quotes its loan charge as a certain rate of discount plus a charge for credit investigation. ${ }^{32}$ Some companies omit the credit investigation fee; others vary it inversely with the size of the loan. Six to eight percent is a common rate of discount. But since industrial bank loans, like personal finance company loans, are paid off in regular installments, the effective interest rate is typically (since the "average" size of the loan is approximately half its face value) about twice the stated rate.

In $193^{8}$ the average size of loan made by a sample of ten Morris Plan banking companies was $\$ 288 .^{33}$ Applying the first of the three criteria, it seems clear from this and other evidence that industrial banking companies, in so far as they make industrial and commercial loans, make them mainly or almost exclusively to small business. While industrial banking companies grant somewhat more favorable rates and other conditions on their larger loans than on their smaller ones, the differential is on the whole not great.

As applied to industrial banks the third criterion is the most important. Large companies almost universally obtain from some alternative source the type of funds that many small concerns obtain from industrial banks. And here there is no comparison between the respective rates and other conditions. A small concern which borrows at an industrial bank is likely to pay a total effective charge of from I2 percent to 20 percent or more per annum for short-term money which a large company can get for I to 4 percent per annum. This comparison is not necessarily a reflection on the industrial banks, which specialize in lending operations which, to be profitable, require relatively high rates of interest.

Small Loan Companies. The activities of small loan companies (otherwise known as personal finance companies) ${ }^{34}$ in some ways resemble those of industrial banks

${ }^{33} I d$, at $9 \mathrm{r}-95$. This statement and the following remarks should be qualified by pointing out that, as already implied, some so-called industrial banks operate under charters which permit them to offer the same services and follow the same procedures as regular commercial banks.

${ }^{33}$ Id. at 85 .

"St Small loan companies are also sometimes called simply "finance companies," a vague term which is frequently applied indiscriminately to any or all of the "intermediate" financing institutions. Cf. Westerfield, Money, Credit and Banking (The Ronald Press Company, New York, 1938) ror 4 ff. 
and commercial bank installment loan departments; but in general they lend smaller amounts and their charges are higher. Most state laws limit small loan companies to loans of $\$ 300$ or less. The law often allows them to charge interest as high as $3^{0}$ to 42 percent on a percent-per-year basis. The quoted rate is usually expressed as a percent per month of the unpaid balance. Keen competition among small loan companies often drives the rate below the legal maximum.

As Young states, ${ }^{35}$ "Practically the entire credit market tapped by personal finance companies is composed of individuals, mainly urban residents, whose annual incomes are between $\$ 500$ and $\$ 3500$." But many of these individuals appear to be business proprietors, and professional people. For example, one of the leading small loan companies reports $s^{36}$ that approximately io percent of the number of loans it makes go to business proprietors, and about 2.6 percent more to professional people other than school-teachers.

The average size of small loan company loans is very small; in 1937 it was only $\$ 447$ for a sample compiled from data supplied by the state banking departments of thirteen states. ${ }^{37}$ Other data indicate that the loans made to business proprietors in Detroit by one of the leading small loan companies generally ranged from $\$ 3135$ to $\$ 18 .^{38}$ Thus it seems clear, in answer to the first of the test criteria, that small loan company loans made for business purposes go to small businesses.

When applied to the small loan company, the second criterion, relating to the comparative rates and other conditions to large as against small borrowers, is hardly applicable since all or nearly all of its business is done with small borrowers. Application of the third test of course leads to the statement that large concerns, who never or practically never resort to personal finance company borrowing, can obtain working money far more economically from several alternative sources. The small business which obtains a personal finance company loan is competitively handicapped not only by paying interest at perhaps 25 percent per annum as against several percent for bank money, but also by having to put up substantial collateral compared to the collateral-free bank loan which the large concern is often able to obtain.

Factors. Factoring companies or factors are concerns which specialize in buying outright the receivable accounts of their clients. The client concern-a textile manufacturer, for instance-usually relies on his factor's advice as to what trade credit he should extend. He then sells all his accounts receivable to the factor without recourse; that is, the factor agrees to take any losses on the purchased receivables.

Factoring companies have been operating in various parts of the world since the fourteenth century. Although there were only some 17 factors (not counting branches) in this country as of 1940 , it is estimated that they did about $\$ 800$ million worth of business. In addition there are in many cities self-styled factoring concerns which do not actually purchase receivables but instead merely make loans on

${ }^{38}$ Ratph A. Young and Assoctates, Personal Finance Companies and Their Credit Practices (National Bureau of Economic Research, New York, I940) $5 \mathrm{r}$.

${ }^{36}$ Id. at 100. $\quad{ }^{38} I d$. at at 99. 
the security of accounts receivable. (Commercial banks and other financing institutions also often make loans on accounts receivable.)

The factors are geographically very poorly distributed, since most of them are located in New York City, with a few companies in Boston, Chicago, and other large cities. In the past, most of the clients of factors have been textile manufacturers, converters, and selling agents. Lately the factors have extended their services into such fields as shoes, home furnishings, petroleum products, radio tubes, lumber, coal, and metal products; but it is estimated that these non-textile fields still account for only about to percent of factoring volume. ${ }^{39}$ In the textile field, the clients of the factors include all sizes of concerns ranging from the smallest to the very largest. For the bulk of their clients the factors hold somewhere between $\$ 30,000$ and $\$ 300,000$ in receivables for each client at any one time, "with most of the factoring business originating in the larger accounts. . . ."40

Appraisal of factor charges is complicated by the fact that the factors do not merely lend money but also render various management services including the selection and collection of risks. The factor's commission, which may run from .75 percent to 2 percent of the sales cashed, is designed to remunerate him for these latter services. In addition he charges interest which, though higher in years past, is now in the neighborhood of five or six percent. Although total charges vary according to the volume and quality of the receivables the client offers, there appears to be no clear evidence that large and small clients receive different treatment.

In terms of the test criteria, then, a large proportion of the factors' clients are in the small business category. The factors apparently offer more equality of treatment to varying sizes of clients than is accorded by most of those financial institutions which are patronized by both large and small concerns. With regard to the last of the three criteria, although the large company can and generally does get cheaper money from its bank connections or out of income than it does in effect from a factor, the "extra" services rendered by the factor help to equalize this differential. Thus the small company which patronizes a factor for the particular segment of its financial needs which the factor is equipped to handle, is not necessarily at a marked competitive disadvantage compared with its larger rival in meeting these particular needs. ${ }^{41}$

Insurance Companies. Insurance companies make mortgage loans on improved residential and commercial property and in some cases on industrial property. Small retailers and owners or purchasers of other small commercial properties, as well as home owners and purchasers, are often able to obtain such mortgage loans.

Insurance companies also extend long-term credits by buying bonds and notes issued by large corporations. The insurance companies are in addition making an increasing number of business term loans other than mortgage loans. To date

${ }^{30}$ SaULNIER AND JACOBY, op. cit. stipra note I8, at 60 .

10 Ibid.

"For an interesting discussion of other services rendered by the factors, see HrLIYER, KEYs To Business Cash (Harper, New York, I942). 
these loans have gone entirely to the larger companies (those with assets of over $\$ \mathrm{I}$ million). ${ }^{42}$ The average individual insurance company term loan has been in the neighborhood of $\$ 3.8$ million. Moreover most of these term loans are unsecured. These loans, while doubtless a proper type of insurance company investment, further increase the credit and capital handicap of small business.

In the future the insurance companies may find it desirable to extend term loans to diversified types of small concerns. This movement may be given impetus by virtue of the fact that insurance companies as lending institutions are expected to be eligible under RFC's new loan-guarantee program (discussed in pages that follow).

Commercial Paper Houses. The commercial paper houses or dealers ${ }^{43}$ provide business concerns with short term funds by purchasing their notes at a discount on the open market and then selling these notes to investors, principally banks. Commercial paper volume outstanding reached its peak (\$r,296 million) ${ }^{44}$ in 1920 and has been much below that level ever since. In January 1945, for example, commercial paper outstandings amounted to $\$ \mathrm{I}_{30}$ million. ${ }^{45}$ The decline in the use of commercial paper is traceable to some of the same factors which reduced the ratio of commercial bank loans and discounts to total commercial bank resources by more than half between I920 and $19400^{46}$ Nevertheless, the commercial paper house warrants consideration in that its rates are so low. As Greef states, ${ }^{47}$ "The average rates on prime paper for the years I919-1935 . . . were undoubtedly lower than the average rates charged by banks on direct loans to their own customers" during the same period. Discount rates have not averaged more than I percent in any year since 1934. In the latter part of I94I the rate for prime commercial paper ( 4 to 6 months $)^{48}$ reached a low point of .50 percent; as of January 1945 , the rate stood at .75 percent. $^{49}$ In addition to the discount the commercial paper dealers charge a commission which ranges from $1 / 8$ of I percent, or less, to $1 / 2$ of I percent of the face value of the paper; the average commission is probably something less than $1 / 4$ of I percent. ${ }^{50}$ Thus in the last few years the total charge to the borrower has stood at less than I percent of the face value of the notes offered. In general the commercial paper house is the most economical institutional source of short-term funds.

\footnotetext{
12 JacoBy and SaULnier, op. cit. supra note 20 , at 3, and passim.

${ }^{43}$ Note brokers, who handled commercial paper on a commission basis without actually purchasing it, were formerly important but are now of minor significance.

4* Greef, The Commercial Paper House in the Untted States (Harvard University Press, Cambridge, 1938) Table 2.

45 (March, x945) 31 Fed. REs. Bull. 252 (table).

${ }^{16}$ Willis, The Functions of the Commercial Banking Systen (King's Crown Press, Columbia University, New York, 1943) ch. 8; GreEF, op. cit. supra note 44, ch. 3 and p. roo; also, the Winter, I939, issue of The Index (N. Y. Trust Co.) 66-67.

${ }^{47}$ GREEF, op. cit. supra note 44, at 320 .

18 U. S. Dep't of Comm., Survey of Current Business, 1942 Supplement, 65.

${ }^{40}$ (March, x945) 3 I Fed. Res. BuLl. 253 (table).

${ }^{50}$ GreEF, op. cit. supra note 44, at 350.
} 
Small business is for the most part unable to take advantage of this low-cost money source. As Westerfield states: $:^{51}$

"In general the open market borrowers are large concerns. . . The reasons for the large proportion of large concerns is that the broker [or dealer], whose earnings come from a narrow commission, does not find it worth his time to bother with the small batches of paper of small concerns. Most of his expenses do not vary with the size of the issue, but are the same for large and small amounts. Furthermore, the brokers find it so difficult to sell paper of concerns having resources from $\$ 100,000$ to $\$ 150,000$ that they usually refuse to undertake such sales, and many cater only to firms with a halfmillion or more assets. The market for the paper of small and less-known concerns is restricted since banks find it harder to look them up and satisfy themselves as to the quality of the paper, although the small concerns are often quite as good for the amount they borrow as are the larger ones for the proportionately large amounts they require."

In terms of the test criteria, the commercial paper houses are practically unavailable to small business as a source of short-term funds; the rates charged by them to small business therefore cannot be indicated. On the other hand large companies that are able to make use of this source can obtain short-term money therefrom at rates lower than from any other standard institutional source.

Equipment Manufacturers and Other Suppliers. Manufacturers of various types of industrial equipment offer financing plans under which the purchaser of the equipment can buy it on terms and pay for it out of income. This affects small business in two ways: in its capacity of manufacturer of such equipment, and in its capacity of purchaser of such equipment.

As purchasers of such equipment small companies are, at least in theory, protected from discrimination as to price or terms offered by the Robinson-Patman Act and corresponding state statutes. Thus the first two test criteria lead to the conclusion that both large and small concerns to some extent use equipment suppliers as sources of credit, and that nominally there is no discrimination as to terms offered. Applying the third test, however, we find the picture clouded by the fact that large companies, far more than small, are able to buy industrial equipment and supplies for cash and thereby not only avoid the cost of special time-payment arrangements but also take maximum advantage of cash, quantity, and trade discounts.

Small business in its capacity of producer of industrial equipment (or, for that matter, of agricultural equipment, consumer durable goods, et cetera) finds itself at a marked disadvantage in that it so often does not have the financial resources which are more and more employed by larger competitors to provide special installment payment provisions for customers. ${ }^{52}$

61 Westerfield, Money, Credit and Banking (Ronald Press, New York, r938) 1006.

"2: The rapid growth of the sales finance company, which buys installment paper from retail and other businesses, has not removed this disadvantage. The rates charged by such companies, though subject to wide variation, are well above the costs encountered by large concerns in handling their own paper or discounting it at their banks. For a discussion of sales finance company charges, see PLomares and Young, Sales Finance Companies and Them Credit Practices (National Bureau of Economic 
Trade Credit. In addition to the forms of installment credit mentioned in the preceding section, small business relies heavily on trade credit extended on a noninstallment basis by manufacturers to wholesalers and jobbers, and by these to retail trade in supplying inventory and equipment in advance of payment. Such credit is highly important to the wholesale and retail trade; ${ }^{53}$ indeed many small wholesalers and retailers could never get started or continue in business without it.

While such credit has probably, at least from the immediate point of view, facilitated the distribution of goods and services, it has a number of disadvantages. In the first place few small companies can say what such credit costs them; if the cost is exorbitant, they frequently do not detect the fact. Second, the presence of attractive cash discounts may and often does mean that those firms who obtain shortterm credit by not taking advantage of the discounts do so only on an expensive basis. Third, much trade credit is really bank credit furnished indirectly through the wholesaler (or other supplier) as an intermediary; the retailer tends to pay two charges on such credit. Fourth, trade credit relationships are not infrequently used for coercive purposes. Wholesalers may with immunity fill orders with inferior goods, or they may threaten to close credit if a retailer tries to carry competing brands. Fifth, the small distributor or manufacturer who is dependent upon trade credit is at a decided disadvantage compared to the company which can get credit from alternative sources; the latter concern can not only "bargain down" the cost of credit, but, more important, it can use its credit to "bargain down" the prices of the goods it buys. Ability to pay cash on delivery or within a few days' time (or even to advance money to help finance the manufacturer or other suppliertrade credit in reverse, this might be called) gives any company a powerful competitive advantage, particularly when it is dealing with small suppliers. Access to adequate "bargaining capital" is indeed one of the most important reasons why large manufacturers and distributors get goods at lower prices. Sixth, small manufacturers, jobbers, and wholesalers, commonly lack the bank accommodations ${ }^{54}$ necessary for them, in their capacity as suppliers of trade credit, to match the accommodations offered by their large competitors.

In terms of the test criteria, a very large proportion of the short-term credit extended by manufacturers, jobbers, and wholesalers goes to their smaller customers. Although satisfactory quantitative data on the subject are scarce, it appears that this credit is often on an expensive basis, that the effective interest rate is often hidden, and that small concerns which become dependent upon such credit are frequently victimized by their regular suppliers or are in a competitively unenviable position when they shop in the open market for goods. For all of these reasons large concerns customarily make slight use of trade credit as such; instead they

Research, New York, 1940), Chapter 8. See also other volumes in the National Bureau of Economic Research series entitled Studies in Consumer Installment Financing; also RetaIL Credit SuRver: 1943 (Board of Governors of the Federal Reserve System, Washington, 1944).

${ }^{53} \mathrm{Sec}$, for example, ReTaIl Credit SuRvey: 1943, op. cit. supta note 52.

is In some situations receivables financing alleviates, though it does not erase, this difficulty. 
tend to finance inventory on a less expensive basis through internal and other external sources of funds.

Private Venture Capital. Prior to the First World War the credit and capital requirements of business, particularly small business, were largely met from local private venture capital. That the private investor still supplies some credit and capital is indicated, for example, in the results of the Commerce study already cited, where about 4 percent of the replying small manufacturers stated that they used personal and private loans to help meet their working capital needs, and 7 percent stated that they used such loans to help meet long-term capital needs. ${ }^{55}$ The personal funds of small entrepreneurs who invest in their own businesses is likewise still a source of capital. For example, of a sample of enlisted service men who in a recent survey indicated definite intentions to start their own businesses, some 45 percent stated that they intended to invest between $\$ 2,000$ and $\$ 10,000$, and 4 percent said they would invest more than $\$ 10,000 .^{56}$

It is plain, however, as these figures themselves help indicate, that the local investor is now of minor importance as a direct source of business venture capital. A number of factors, most of them revolving about the fundamental changes that have taken place in the technological bases of our economy, are responsible. New methods of transportation and communication, new production techniques, and the growth of production for a national market which these other changes made possible, destroyed the investor's earlier orientation primarily in terms of his own community; and the new "big-time" ventures often required so much capital that local sources could not supply it anyhow. The concommitant rise of nation-wide security markets, and of security speculation, provided expanded outlets for investment which drew funds away from local investment. The growth of metropolitan areas helped destroy the personal contacts which were the basis of much of the older investment activity. The private investor as a source of venture capital now tends to be looked upon by most large businesses, and many small ones, not as a standard way to obtain risk money but as a sort of last resort. This is clearly implied in the Commerce study which indicates that more than twice as many of the sampled small manufacturers reporting credit difficulties relied on personal and private loans as those reporting no credit difficulty.

Application of the test criteria appears then, to lead to the following conclusions: While private investors enter into direct, active financial participation in small ventures much more frequently than in large ones, the whole tendency in recent years has been for them to use their resources for "passive" investment in the security issues of large corporations or of the government. Moreover the typical private investor is willing to accept a much lower return from his "safe" portfolio of government or large corporation securities; conversely, he tends to expect a "speculative" return as well as a normal rate of interest from any money he puts in a small enter-

${ }^{56}$ Op. cit. supra note 7, at 66.

${ }^{\circ 0}$ Myers, Post-War Business Plans of GI's (Jan. I945) Domestic Commerce II, also, the same author's Small Business for Veterans, this symposium, p. 344 . 
prise. He also frequently demands a share of actual control. Thus the large concern is generally able to obtain money indirectly from the individual private investor far more economically than the small concern can obtain it directly.

The Capital Markets. Although use of the capital markets is a standard method by which the large corporation can obtain funds, the source is largely unavailable to small business. This is suggested by the Commerce survey, which found that only some I2 percent of the replying manufacturers stated that they made any use of stock or bond issues for meeting long-term capital requirements.

As Gromfine states on the basis of SEC data:

"For all practical purposes the organized capital markets are closed to small business. The cost of small security issues (less than $\$ 250,000$ ) is seldom less than ro percent and sometimes almost 25 percent of the issue. It ranges up to five times the cost to large companies and makes financing through the sale of stocks and bonds highly impractical for small firms."

Contrary to popular impression, the cost of SEC registration is not an important factor in explaining the difficulty of small issues. The statute has permitted exemption from registration of issues of less than $\$ 100,000$; an amendment has recently increased the exemption limit to $\$ 300,000 .{ }^{58}$ Where registration is necessary, studies by the SEC based on the period 1938-1940 show that the cost of registration for issues of less than \$I million averages only 6.56 percent of the cost of flotation of the issue (not of the total amount of the issue). ${ }^{59}$

Moreover, even when the small firm does pay the expense of an issue, it is apt to have great difficulty in selling it. For example, another SEC study ${ }^{00}$ shows that only 24 percent of the value of securities registered by 757 unseasoned companies, mostly small companies, were actually sold. Of these issues, 497 were for new ventures for which only I5 percent of the amount registered could be disposed of; even the remaining 260 companies, which were going concerns, sold only 40 percent of the amount issued.

Summarizing in terms of the test criteria, it appears that in spite of difficulties a minority of small firms obtain capital through security issues, but that the cost to them of obtaining money this way is several times the cost to large concerns. And since, once issued, the securities of small companies are generally only partially sold, the cost to them is apt to be again doubled or multiplied several-fold.

Parent Companies. If a small company is an affiliate of another concern, it can often obtain funds from the parent company. A small minority of the manufacturers included in the Commerce study stated they obtained short or long-term

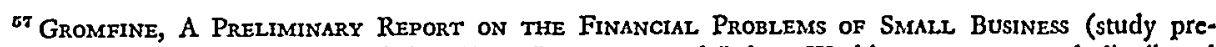
pared in the Bureau of Labor Statistics, U. S. Department of Labor, Washington, 1943, and distributed by the Smaller War Plants Corporation for administrative use) 57.

${ }^{58}$ Public Law 55, 79th Cong., Ist Sess. (I945), ch. I22. On effects of securities regulation, see later in this symposium, Margraf, Does Securities Regulation Hinder Financing Small Business, p. 301.

${ }^{59}$ Cited by Weissman, op. cit. supra note 15 , at 58 .

${ }^{\circ}$ S. E. C., Sales Record of Unseasoned Registered Securities (ig4I) p. 3 and Table i.
} 
funds in this manner. ${ }^{61}$ Or if a small concern is presently not affiliated it can frequently become so if it wants. Many large manufacturers, mail order houses, etc., are constantly on the lookout for small firms-especially those making more or less unique products-which they can take over as branches or affiliates. Similarly, oil companies, chain drug stores, grocery chains, etc., often seek retailers whom they can buy out, take a financial interest in, or establish as more or less independent outlets. Credit relief is often stressed as an advantage in such proposals.

By definition any such affiliation implies a loss of independence; and many is the small businessman who, prodded by his acute need for working or long-term money, has got it at the expense of losing all effective control over his company. Yet the syllogism must not be applied carelessly. Affiliation may in some cases increase the capacity and efficiency of the small concern; the Research Institute of America goes so far as to say" ${ }^{62}$ that "Odds are that the small manufacturer, supplier or distributor who associates himself with a large company has the most secure future." But it adds that "On the other hand, many companies don't want to pay the price of their independence which such association frequently costs." Moreover concentration of business control has economic, political, and even sociological implications far beyond the immediate effects on the concerns directly involved.

Though they cannot be examined in this article, it is possible that affliated groups of small concerns may prove as effective for peacetime production as they have in some instances for wartime production. A related possibility is for groups of small firms jointly to set up special service organizations designed to provide financial, technical research, accounting, and similar services on a larger scale than any of the members could individually manage. ${ }^{63}$

Private Industrial Development Groups. Although it cannot be treated in this paper, another source of small business funds, particularly long-term loan and equity funds, is the private industrial development group. A companion article in this symposium describes one such group-the Baltimore Industrial Corporationwhich has operated on a modest but successful scale for a number of years. The Louisville Industrial Foundation is another well-known example. ${ }^{64}$

Ferdinand Eberstadt, in a recent address ${ }^{65}$ on the financial problems of small business, concludes in part as follows:

With all these conditions and circumstances in mind, I suggest for your consideration that local communities might tackle the job of furnishing capital to small and new enterprises by forming local investment companies or pools of capital to be obtained

${ }^{01}$ Op. cit. supra note 7 , at 66 .

03 Research Institute of america, The Smailer Company After the War (1944) 2.

${ }^{63}$ On these two possibilities cf. Business WeEk, Sept. 4, 1943, p. 34, and Modern Distribution, April 13, 1945, p. 2.

o4 Cf. Hopkins, The Louisville Industrial Foundation: A Study in Community Capitalization of Lochl INdustries (Federal Reserve Bank of Atlanta, 1945).

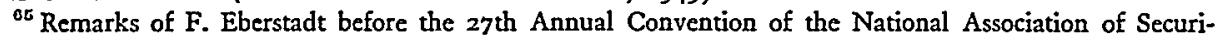
ties Commissioners at St. Louis, Missouri, on December I2, I944 (mimeographed: F. Eberstadt \& Co., New York). Reprinted in Commercial \& Financial Chronicle (New York) December 2I, I944, p. 9. 
from local businesses, banks, and public spirited citizens without imposing an undue burden on any individual or group. If certain reasonable requirements are met, government could well supply additional funds through preferred stock as it did to the banks. Perhaps such companies could be encouraged through special State and Federal tax advantages.

Such organizations could purchase equity shares in small and new enterprises, holding them for a time, subject to redemption out of profits, or to be disposed of through local investment dealers. ...

The Investment Bankers Association has recently backed the principle implicit in Eberstadt's proposal by formally recommending a nation-wide system of local community investment companies. Under the IBA program the Board of Governors of the Federal Reserve System would have authority to grant charters to local investment companies. The Federal Reserve bank of the particular district would be obligated to purchase debentures of the local company up to an amount equal to three times its paid-in capital. The local company would be authorized

to purchase for investment or resale mortgage bonds, debentures, preferred and common stocks of corporations within the Federal Reserve District, and to make loans to unincorporated businesses. The amount of such loans made to, or securities purchased at any one time from a single issuer would be limited to $\$ 100,000 .{ }^{60}$

It is perfectly true that the record of private industrial development groups has to date been spotty. ${ }^{67}$ Such groups have, for example, often been used as devices to enable a few men to preempt control of promising local ventures. Yet it is reasonable to suppose that such tactics need not characterize private industrial development groups. As an analogy, certain of the more flagrant practices commonly employed by corporations in the "empire-building" days of the late nineteenth and early twentieth century have been outlawed by statute or have otherwise become unfashionable. Private industrial groups can be regulated by special legislation if necessary. The evidence suggests that, as sources of long-term financing as well as technological, production and marketing assistance, such groups may warrant much increased attention in the future. In terms of the three criteria, these groups already appear in at least a few instances to have provided most of their assistance to medium-sized or small concerns; to have helped small concerns obtain equity and other long-term funds more economically than through alternative sources; and to have made it possible for small companies to reduce their handicap compared to large companies in securing funds and other assistance.

\section{Public Sources}

Federal Reserve Assistance under Section ${ }_{13} b$. In 1934, in the midst of great business hardship, Congress amended the Federal Reserve Act to include Section I3b, authorizing direct loans by Federal Reserve banks. ${ }^{68}$ This was a departure

${ }^{\circ 0}$ Journal of Commerce (New York), April 25, 1945, pp. I and 6.

oi Cf. Ch. of Comm. of U. S., Community Industrial Financing Plans (Washington, mimcographed, undated but issued in 1939).

${ }^{88} 48$ STAT. 1105 (1934), 12 U. S. C. (1940) \$352a. 
from the original central bank theory which held that the Federal Reserve banks should be restricted to dealings with banking institutions. At the time it was enacted, many considered Section $13^{b}$ a somewhat radical measure. Section $I_{3} b$. permits the Federal Reserve banks to make direct loans to any established industrial or commercial enterprise, provided the concern is unable to obtain from the usual sources the necessary financial assistance on a reasonable basis. The maturity of any such loan must be not more than five years, and the loan is to be used for working capital purposes only. Section $\mathrm{I} 3 \mathrm{~b}$ also authorizes any Federal Reserve bank to enter into participation commitments with other banks in its district to take over up to 80 percent of a loan either when the loan is made or at any time the local bank should desire it. The act also provides for the appointment of industrial advisory committees in each Federal Reserve district to make recommendations on all $\mathrm{i} \mathrm{z}^{\mathrm{b}}$ loans.

Under Section $\mathrm{I}_{3} \mathrm{~b}$ and other powers already possessed, the Federal Reserve banks may thus make loans directly to a borrowing firm, discount for or purchase such obligations from any financial institution in their districts, make loans to the financing institution on the security of these obligations, or enter into participation commitments with regard to such discounts or loans. In a regulation issued shortly after the Act of 1934 became law, the Federal Reserve Board stated that in passing the Act, Congress had recognized "the need of many small and medium-sized industrial and commercial businesses for additional working capital to enable them to resume normal operations and to maintain employment or provide additional employment." ${ }^{\text {"60 }}$ This was confirmed by a press release issued about the same time which stated that loans under Section I3b would be chiefly "to small and mediumsize enterprises, which have the greatest need for such assistance."70

Activity under Section I3b reached its peak in 1935. At the end of that year; total credit outstanding amounted to $\$ 69$ million. Of this total, $\$ 32$ million $^{71}$ was in Federal Reserve bank loans outstanding, $\$ 28$ million was in Federal Reserve bank commitments to make advances, and $\$ 9$ million was in financing institution participations not covered by Federal Reserve bank commitments. ${ }^{72}$ Even these peak amounts were not large in view of some appraisals of the magnitude of unfilled business credit needs or in comparison with the operations of the commercial banks, the Reconstruction Finance Corporation, or the Smaller War Plants Corporation. Since I935, although there has been a mild increase in participations by financing institutions, operations under Section $13 \mathrm{~b}$ have declined rapidly. There

${ }^{\circ}$ I2 CODE FEd. Regs. (I939), Explanatory Letter following \$219.8 (Federal Reserve Board: "Discounts, Purchases, Loans and Commitments by Federal Reserve Banks to Provide Working Capital for Established Industrial or Commercial Businesses, Regulation S, approved June 26, 1934" [Washington, I934] I).

${ }_{70}$ Press Release, Federal Reserve Board, June 28, r934, reported in (July 1934) 20 FED. REs. BuLl. $429,430$.

${ }_{71}^{430}$ On the basis of additional data obtained from the Federal Reserve Board, it appears that only about $\$ 20$ million of this total was in the form of direct advances to business enterprises.

${ }^{73}$ (March 1945) 3I Fed. Res. Bull. 239 (table) with additional interpretation by Federal Reserve authorities. 
was a slight increase in activity in the early defense and war period, but by the end of I944 obligations outstanding reached the lowest point in the history of the program and were of negligible proportions. ${ }^{73}$ For the war period the chief explanation for the collapse in lending and participation activity under Section $13 b$ is the large war production loan program inaugurated in mid-ig42 under Federal Reserve Regulation V. The steady decline before the war is somewhat more difficult to account for; the common explanation that the need for credit under Section $1_{3} b$ passed with the end of depression conditions is not reassuring. Other possible reasons are that RFC credit facilities received far more publicity, and that the $13^{b}$ program was handicapped by the requirements that loans be only for working capital (so that they could not, for example, finance the purchase of machinery), only for established enterprises, and with a maximum maturity of five years.

Although the program based on Section $\mathrm{r}_{3} \mathrm{~b}$ was announced as being primarily for small and medium-sized business, this part of the business community turned out in practice not to be the major recipient of funds. For example in the second half of 1937, the latest period for which data are available, only 21 percent of the industrial advances, including commitments, approved by the Federal Reserve banks were reflected in loans of $\$ 50,000$ or less. Seventy-nine percent were reflected in loans of over $\$ 50,000$, and 30 percent were reflected in loans of over $\$ 400,0000^{74}$ If small borrowers are defined as those requesting loans of $\$ 10,000$ or less, then only 3 percent of the funds allotted were to borrowers of that type. It is true that a substantial proportion of the number of loans, as distinguished from the amount of funds, went to small concerns; but, particularly in view of relative needs, this is not a satisfactory test.

A bill ${ }^{75}$ (known as the Wagner-Spence bill) recently introduced in the Senate, and a companion measure ${ }^{76}$ in the House, would further amend the Federal Reserve Act to remove the direct lending provision of Section $\mathrm{I}_{3} \mathrm{~b}$ and instead to permit the Federal Reserve banks to guarantee up to a 90 percent of any bank loan to a business enterprise. ${ }^{77}$ The restriction that loans may be for a maximum of five years and for working capital purposes only would be removed. These bills carry the endorsement of the Chairman of the Board of Governors of the Federal Reserve System. Federal Reserve is a central agency in the recommendations (already mentioned under private industrial development groups) of the Investment Bankers Association. Rudolph L. Weissman has proposed the creation of a Federal Reserve Investment Corporation based in part on the Federal Reserve System. His

${ }^{78}$ Ibid.

" Based on data in "Twenty-Fourth Annual Report of the Board of Governors of the Federal Reserve System, Covering Operations for the Year I937" (Washington, 1938) 6I.

${ }^{75}$ S. 5II, 79th Cong., Ist Sess., introduced February I2, I945.

${ }^{78}$ H. R. 59r, 79th Cong., rst Sess. (I945).

${ }^{77}$ It would seem worthwhile to consider modifying these measures to set a maximum-perhaps $\$ 200,000$ - on the individual size of loan which could be guaranteed by Federal Reserve; or criteria resembling those employed by Smaller War Plants Corporation (see infra note 90) might be incorporated. 
recent book ${ }^{\mathbf{7 8}}$ also summarizes other proposals for increasing the Federal Reserve System's usefulness to small business.

Summarizing in terms of the test criteria, the bulk of the funds lent or committed under Section $x_{3} \mathrm{~b}$ have (judging by size of loan as the only available basis) gone to large rather than small business. Although the data on this point are meager, interest rates and collateral requirements-whether of the Federal Reserve banks making direct loans or of the banks making loans on the basis of Federal Reserve participation or commitments-have apparently been more liberal for the larger loans. Large corporations have been able to get working capital either from the Federal Reserve banks themselves or from other sources at less cost than small companies have been able to get it under Section $\mathrm{r}_{3} \mathrm{~b}$.

Reconstruction Finance Corporation Activities under Section 5d. The RFC was first authorized to make loans to industry in 1933 under the so-called N.R.A. program for lending funds through mortgage loan companies. It was in 1934, however, that Public Law $4 \mathrm{I} 7$ (73rd Congress), already referred to as having added Section $13 \mathrm{~b}$ to the Federal Reserve Act, also added Section $5 \mathrm{~d}$ to the Reconstruction Finance Corporation Act. Section $5 \mathrm{~d}$, though subsequently amended a number of times, has since 1934 served as the legislative basis for business loans. As amended, it stipulates that RFC is permitted "to purchase the securities and obligations of, and to make loans to, any business enterprise when capital or credit, at prevailing rates for the character of loan applied for, is not otherwise available. ${ }^{79}$ Such loans or purchased securities must be "of such sound value, or so secured, as reasonably to assure retirement or repayment." This last provision, inserted in I938 in lieu of the earlier blanket "adequately secured" would seem to permit RFC to make unsecured character loans; but the then chairman, in testimony before a congressional committee, ${ }^{80}$ felt that the amended Act did not permit such loans. The Act contains certain other lending criteria, such as that the borrowing firm must be in a solvent condition and that loans may be made in participation with banks. Section $5 \mathrm{~d}(2)$, added in I94I, permits RFC to make loans for national defense purposes. RFC has also become the processing agent for all applications, originating with banks and other financial institutions, for business loans made to veterans of the Second World War and guaranteed by the Veterans Administration under Public Law 346, 78th Congress (the so-called "G. I. Bill of Rights" Act). This function includes a recommendation in each case as to whether the application warrants a guarantee.

As of the end of December, I944, RFC had made loans and commitments to business enterprises for other than defense purposes totalling $\$ 66 \mathrm{I}$ million. ${ }^{81} \mathrm{Al}$ though RFC's legislative basis would appear to have allowed it to serve as a primary source of small business credit, and although numerically speaking a considerable

${ }^{78}$ Supra note 15.

${ }^{80}$ Hearings on $H . R .4012$ (H. R. $33^{8} 3$ ), February 7-9, r939; cited in T. N. E. C., Problems of Small Business (Monograph No. 17, Senate Committee print, 76th Cong., 3d Sess., 1941) 228.

${ }^{81}$ RFC, Release of January I0, 1945, p. 3. 
proportion of RFC's loans and commitments have been for small concerns, the vast bulk of the $\$ 66 \mathrm{I}$ million total has been employed for the benefit of large companies. If small borrowers are again arbitrarily defined as those asking for $\$ 10,000$ or less, then only some 3.5 percent of RFC's funds have been used for the benefit of this class of borrower. Only 16.5 percent of RFC's loans and commitments have gone to borrowers of $\$ 50,000$ or less. The picture for RFC defense loans is even less favorable to small business; 74 percent of the funds were allotted to loans of more than one million dollars.

Interest on RFC loans has been reduced from an earlier 6 percent to 4 percent. The interest rate on all RFC loans is stated by RFC authorities to have been 6 percent from April I, I934 (when lending operations under Section 5 d began) to May 15, 1935; uniformly 5 percent from then until April I, 1939; and uniformly 4 percent from that date to the present. ${ }^{82}$ Banks participating with $\mathrm{RFC}$ have, from the start of the program, been allowed to charge a maximum interest rate of 6 percent on their portion of the loans. Unlike commercial bank term loans, practically all RFC term loans have been secured. Forms of security have included mortgages or liens on fixed assets such as real estate, plant, and equipment, pledge of inventories, assignment of accounts receivable, cash surrender value of life insurance policies, and endorsements of stockholders and others with independent financial resources. 83

On March I, I945 the Board of Directors of RFC passed a resolution ${ }^{84}$ providing for a liberalized program under Section $5 \mathrm{~d}$. Under this program RFC has notified all banks in the country that it stands ready to execute a "participation" offer for any portion through 75 percent of any loan the bank wishes to make to a private enterprise, so long as the loan is for not over $\$ 250,000$ and conforms to certain other conditions. Interest on the guaranteed portion of the loan must not exceed 4 percent, $^{85}$ though the bank can charge up to but not exceeding 6 percent on the unguaranteed portion. Government participation may be either on a deferred basis, with a pledge to come in on ten days' notice whenever requested, or on an immediate basis.

\footnotetext{
${ }^{82} \mathrm{RFC}$ authorities state that on some loan contracts in the hands of borrowers the intercst rate is still stated as 5 percent or 6 percent, but that on all such contracts the borrower has been billed only at the standard RFC interest rate prevailing at the time the billing was made.

${ }^{83}$ JACOBY AND SAULNIER, Op. cit. supra note 20 , at 6r.

84 Reconstruction Finance Corporation: Resolution, dated March I, 1945.

${ }^{85}$ The Government guarantee charge (also called a participation charge, though this term might well be reserved for participation loans involving joint advances of funds) is as follows: wherc the RFC guarantees over 75 percent and up to 90 percent (the maximum guarantec), of the loan, the guarantec charge is I percent per annum of the guaranteed portion of the loan; where RFC guarantees over 50 percent and up to 75 percent, the guarantee charge is $3 / 4$ of $x$ percent; and where RFC guarantees up through 50 percent, the guarantee charge is $1 / 2$ of I percent. (Under the new program, guarantecs through 75 percent are handled under a blanket standard-contract agreement; guarantees above that pereentage require special approval of the RFC Board of Directors.) In every case the bank retains the balance (ranging from 3 to $3^{1 / 2}$ percent) of the 4 percent interest rate to the customer on the guaranteed portion of the loan. This makes an attractive investment for the bank; for example, alternative investment in U. S. Government bonds of long maturity would, on the basis of current yields, return only around $2^{1 / 2}$ percent, and Government bonds of maturities comparable to those of the guaranteed loans might yield less than 2 percent.
} 
Perhaps the most interesting innovation in the new program is that amortized loans with a maturity of up to ten years are permitted. Heretofore, although the amended RFC act has not required it, maturities have generally been kept to five years.

Applying the test criteria, it is clear that most of the money RFC has up to the present advanced under Section $5 \mathrm{~d}$ has been used for the benefit of large rather than small business. RFC interest rates have, however, been twice reduced and have apparently been uniform for large and small borrowers. ${ }^{86}$ RFC security requirements, though they have probably shown some variation as between large and small concerns, have been much more uniform in this respect than security requirements on bank term loans. On the other hand term loans obtained by small concerns from RFC have often or generally been at higher cost and for shorter maturities than large concerns have been able to get similar funds from banks, for example.

Although it is naturally too early to appraise the probable results of RFC's new program, if it is pursued vigorously and with particular emphasis on small business term loans, drastic alteration of some of the foregoing statements may become possible.

Smaller War Plants Corporation. Congress created the Smaller War Plants Corporation in I942 by enacting the so-called Murray-Patman Bill as Public Law 603 (77th Congress). The act stated that the new corporation should have capital stock of $\$ 150$ million subscribed for by the Government through the Secretary of the Treasury. ${ }^{87}$ The Act vested the management of SWPC in a Board of five directors appointed by the Chairman of the War Production Board. A more recent statute $^{88}$ extends the life of SWPC to December 3x, I946 (instead of to June 30 , I 945 as provided in the original Act) and transfers the power of appointment of the directors to the President.

Among the fiscal powers which Section $4(f)$ of the Act delegates to SWPC are the power to make loans; the power to make bank participations; the power to purchase land, buildings, equipment, etc.; and the power to lease, sell, or otherwise dispose of, land, plants, supplies, and the like. Specifically framed for the benefit of small business, the Act gives SWPC broad discretion to determine those who should receive financial assistance, the specific objects and purposes of such financing, and the terms and conditions to be set.

While in the early period of its existence SWPC served primarily as a procurement agency assisting small business in obtaining war contracts, its lending powers have in the last year and a half assumed great importance. The basic loan policies which SWPC employs in practice ${ }^{89}$ are as follows:

\footnotetext{
${ }^{80}$ Participating banks have on the other hand often or usually charged more interest on their share of small loans than on their share of large loans.

${ }^{87}$ Late in 1944 Congress passed a bill increasing the capitalization of SWPC to $\$ 350$ million. Act of Dec. 8, 1944, ch. 549, 58 STrT. 799 .

${ }^{88}$ Act of April 27, I945, Public Law 42, 79th Cong., Ist Sess.

${ }^{80}$ This information is based largely on SWPC internal memoranda; they are restated in more general terms in the SWPC official pamphlet entitled Loans to SMaLl Business (Washington, I945).
} 
I. The applicant must be a small ${ }^{90}$ manufacturing plant which adds to the value of some product.

2. The applicant must be engaged, or expect to be engaged, in the production of goods for war or essential civilian purposes.

3. There must be a reasonable prospect that the loan will be repaid.

4. The applicant's bank must always be offered the opportunity to take all or part of the loan.

Under its regular program SWPC makes term loans of from one to five years as well as short term loans. On all loans, and regardless of size of loan or size of company, SWPC charges a uniform interest rate of 4 percent. However, when the loan is in participation with a bank or other private lending institution-and there is increasing bank participation in the SWPC loan program-the bank may charge as much as, but not more than, 6 percent for its share of the loan. The regional SWPC loan agent passes upon SWPC loans of \$25,000 or less; other loans are approved in Washington. Leases are approved in Washington.

By virtue of a legislative compromise at the time Public Law 603 was enacted, an RFC subsidiary, the Defense Plants Corporation, was authorized to service all SWPC loans and leases. Under a subsequent agreement the managers of RFC loan agencies have also until recently disbursed all applications for financial assistance approved by SWPC. This strange tripartite arrangement, though partly justified by an emergency situation in which RFC and DPC had field loan disbursing and servicing facilities whereas SWPC had none, is alleged by some observers to have caused delays and inefficiencies in SWPC operations because SWPC loans have had to be closed and disbursed in accordance with a complicated RFC code and closing schedule which was not designed for joint RFC-SWPC operations. SWPC has recently opened a trial disbursement office to serve the Philadelphia area.

In addition to its regular loan program under authority of Public Law 603, SWPC has the power to provide the following three other types of financial assistance:

I. Under authority of the Contract Settlement Act of $1944^{01}$ and of regulations issued by the Office of Contract Settlement, SWPC makes termination loans or "T-Loans"92 to small manufacturers who have been engaged in war productioneither as prime contractors or subcontractors-and whose war contracts have been terminated for the convenience of the Government. Such loans are intended primarily for reconversion purposes.

${ }^{00}$ For lending purposes, SWPC defines a small plant as one employing less than 500 wage carners, exclusive of office and sales personnel; or a branch or subsidiary of a corporation whose total employment, including main plant and branches and subsidiaries, is less than 500 wage earners; or, by way of exception, a plant which employs more than 500 wage earners but whose dollar volume of output accounts for a relatively small percentage of the total output of its industry; or, by way of exception, a plant which employs more than 500 wage earners but whose operation is necessary to the relief of economic distress in loose labor areas, particularly if it is the main source of employment in its community.

${ }^{21} 58$ STAT. 649, 18 U. S. C. A. (Supp. 1944) §ror et seq.

${ }^{92}$ Commercial banks, industrial banks and other financial institutions are also eligible to make "T-Loans." 
2. The Surplus Property Act of $1944^{93}$ authorizes SWPC to make loans to small business for the purpose of purchasing Government surplus property. SWPC has formulated policies for participation in surplus property disposal under this statute.

3. The Veterans Administration on January 16 , I945, designated SWPC as a processing agent for business loans to be guaranteed by the Veterans Administration. While, as noted above, RFC processes applications from banks and other lending institutions operating under federal or state supervision, SWPC processes all other applications, including particularly those from equipment manufacturers desiring to sell equipment to veterans on a deferred payment basis.

SWPC lending activities have been, in practice as well as in legislative theory, mainly for small business. As of the end of 1944, SWPC was making loans and leases at the rate of approximately $\$ 1.2$ million per day. ${ }^{94}$ Of the total funds, cumulated through the end of I944, which SWPC has made available to business enterprises, 30 percent has been in amounts less than $\$$ I0,000 and over 75 percent has been in amounts under $\$ 50,000$.

Summarizing in terms of the test criteria, all of the financial assistance provided through SWPC has been for the benefit of medium-sized or small business; and most of it has been for small business. In terms of rates and other conditions for assistance, there has been less discrimination as between small and large borrowers by SWPC than by the other public agencies reviewed or by most of the private agencies reviewed. On the other hand large business is often able to obtain both short-term and medium-term money from the sources to which it has access more economically than small business is able to obtain such money from SWPC.

Public Industrial Development Groups. In addition to the private industrial development groups mentioned in Section III, there is at least one current example $^{95}$ of a similar public ${ }^{96}$ effort designed to assist in providing long-term financing for manufacturing enterprises. ${ }^{97}$ This is the State of Mississippi's programknown as the "BAWI" (balance agriculture with industry) plan-under which the State has authorized and assisted local governmental units to issue bonds, under state direction and control, for the purpose of providing buildings and equipment to be used for manufacturing purposes by client concerns. This experiment is ably

${ }^{03} 58$ SтAт. 766, 50 U. S. C. A. (Supp. 1944) §I6I et seq.

04 Press Release, Smaller War Plants Corporation, December 29, 1944.

${ }^{\circ T}$ For an interesting case involving an earlier analagous program in North Dakota, see Green v. Frazier, 253 U. S. 233 (I920).

${ }^{\circ 0}$ It is probably impossible to establish any precise line of demarcation between public and private industrial development groups. For a discussion throwing light on this point, see HopkiNs, op. cit. supra note 64 , at $x-5$.

${ }^{07}$ Public bodies have of course directly financed many types of utilities in this country, including transportation lines, electric power facilities, waterfront facilities, et cetera. In addition a number of states have promoted, and financed the preliminary development of, mineral deposits. This discussion is limited to cases where public bodies have directly sponsored, and partially financed, private manufacturing or service ventures other than utilities or ventures for the purpose of exploiting natural resources. 
described in a study ${ }^{98}$ issued by the Federal Reserve Bank of Atlanta. It is likely that the public industrial development group deserves, particularly in terms of its potential role in providing equity and other long-term financing for small business, much more study and attention than it has hitherto received. ${ }^{90}$

\section{Profit in Lieu of Outside Sources}

Undistributed profit has traditionally been regarded as the best source of capital for both short-range and long-range purposes. In the past many companies financed their expansion, usually on a relatively slow but sure basis, through profit-ploughback. Some concerns-notably the Ford Motor Company-have relied exclusively on profit to finance their expansion to great size; but that is not typical.

Reliance upon profit for operating and expansion needs reduces the likelihood of outside influence and control in the management of company affairs. Capital obtained out of income is also generally an economical source of funds. Yet money retained from profits to finance expansion or for working capital purposes is not "free" because (quite aside from any sacrifices entailed in earning it) if it is not kept for these purposes it can be invested elsewhere or distributed as dividends which tend to make investors look upon the company as a good place to put their funds.

Moreover, ploughed-back profits may not offer a sufficient volume of funds to implement ambitious expansion plans. It is common knowledge that, usually in spite of favorable balance sheets, most of the country's large corporations rely on security issues and other outside sources of money to complement the internal source. Typically it is through acquiring capital "in the grand manner," not simply by building from within, that a corporation comes to dominate a particular market; conversely, if in the modern economy a firm is content to rely on "slow-but-sure" expansion through the traditional profits plough-back, it is likely to find that the more aggressive fiscal tactics of competitors (which in turn make possible more aggressive product research, market research, sales promotion, et cetera) will drive it from part or all of its present market.

Thus the large corporation may finance expansion and current operations directly through the plough-back, or indirectly by employing profits as collateral to obtain low-cost loans or by distributing profits in such a manner as to build a reputation for its security issues; and these indirect applications of profits have steadily grown in importance.

The smaller company, on the other hand, is typically at a disadvantage, first

${ }^{88}$ Hopkins, Mississippi's BAWI Plan: An Experiment in Industrial Subsidization (Federal Reserve Bank of Atlanta, r944). See also Rauber, The Arabama State Docks: A Case Study in State Deveropment (Federal Reserve Bank of Atlanta, 1945).

${ }^{99}$ Public Industrial Development groups might in the future provide (as some of the private industrial development groups already provide) technological assistance and other management aid or counsel for small ventures they seek to encourage. There is, incidentally, a noticeable tendency on the part of financing institutions, including commercial banks and insurance companies, to put managerial provisions into loan contracts. 
because it has to employ its profits in a more limited manner, and secondly because it has less profits available. It has already been pointed out that the small company has only limited and expensive access to the securities markets, and that it has great difficulty borrowing outside money, particularly term money, at advantageous rates. On the score of profits available, Professor Crum's painstaking analysis of corporate size and earning power concludes that, in terms of profits after taxes, "The larger the corporation the higher is the rate of return, on the average; and this relation holds, with surprising constancy, in each of the size years I93I-I936" covered by the investigation. ${ }^{100}$ If only those corporations which actually made a profit are considered, there is "some indication" that the returns for the smaller size classes were greater than those for the larger; but though some small deficit corporations may be "constitutionally" marginal, many deficit corporations are in that predicament simply because they are "unseasoned." A study recently appearing in the Federal Reserve Bulletin ${ }^{101}$ tentatively concludes that during the war period the earnings of small businesses (both before and after taxes) increased more rapidly than those of large concerns; but there is no indication that this situation will sustain itself after the emergency.

It is well to note, finally, that present tax laws are for two general reasons particularly burdensome on the small company: first, because present taxes particularly affect the expanding concern and the small company very often is (or otherwise could be) expanding; and secondly, because tax withdrawals are particularly serious for the small concern because of its limited access to the money market. Present tax policies thus make small business term loans, and other intermediate and longterm sources of small business funds, more necessary than ever.

Applying the test criteria to profits as the internal source of funds, it appears clear that at least in the years before the war emergency, this source was more widely available to large concerns than to small ones. Profits tend to be a more voluminous and economical source of funds for large concerns than for small, because large companies make important indirect use of profits as collateral for loans from various sources and as a performance indicator to help float security issues. These funds obtained indirectly from outside sources commonly place large firms at a marked competitive advantage over their smaller rivals.

\section{Conclusion}

The evidence presented in this paper appears to lead to the view that small business is at a marked competitive disadvantage when it seeks to meet its credit and capital needs. Small concerns generally obtain short-term bank loans only on terms considerably more onerous and expensive than large concerns can secure the same type of funds from banks or in the commercial money market. From no source

${ }^{100}$ Crum, Corporate Size and Earning Power. (Harvard University Press, Cambridge, I939) 32.

${ }^{10 x}$ Dirks, Wartime Earnings of Small Business (Jan. I945) 3I Fed. REs. Bull. I6. Cf. Working Capital for Small Business (Nov. 1944) Conference BonRD Business Record (National Industrial Conference Board, Inc., New York) which comes to somewhat different conclusions. 
can small concerns obtain short-term credit as inexpensively as large business can obtain similar funds from the sources at its command, the nearest exceptions usually being the factors, the Smaller War Plants Corporation, and RFC. Small concerns commonly have difficulty in obtaining intermediate or long-term credit from private sources, and where they are able to do so, it is only at substantially greater sacrifice than large concerns can obtain the same type of money. In general the nearest exceptions to this statement are term loans offered in some cases by local or state development groups and by two public agencies (SWPC and RFC); but even these funds are not on a basis to equalize the differential. Small business is not in general able to obtain equity funds on any reasonable basis from the organized capital markets; and even in the use of its relatively sparser profits for plough-back purposes small business is at a competitive disadvantage. It is a reasonable deduction that the competitive handicap faced by small concerns in meeting their credit and capital needs is one important cause of the general competitive disadvantage in which they often find themselves.

There are two appropriate vantage points from which one may regard the problem of lack of small business access to adequate loan funds on competitively equal terms. In the first place one may-for example in the case of the commercial banks -postulate that the rates and other conditions set for loans to small borrowers are "discriminatory." There have been numerous discussions of relative bank risks and costs for large and small loans, ${ }^{102}$ and most of them agree that the cost (including allowance for losses) of making and servicing small commercial loans is markedly greater than the cost of making and servicing large loans. Yet one might argue that, because of the relative bargaining positions of large and small concerns and for other reasons, the differentials in rates and other conditions are often greater than warranted by cost differentials. ${ }^{103}$

As a second vantage point one may postulate that present sources of small business funds, notably the commercial banks, are inadequate not because of any significant arbitrary discrimination in rates and other terms, and not because of any lack of lendable funds, but because the national interest requires an entirely new set of credit policies oriented in terms of socially desirable, not simply bankable, risks.

Under this second postulate one may advance either or both of two arguments. It is possible to claim that the banks, in order to make ends meet, can never modify their policies in favor of "socially-oriented" programs, and that therefore (assuming that other private agencies cannot do so) it will be necessary to have governmental assistance to provide equal small business access to credit and capital. As an edi-

\footnotetext{
${ }^{102}$ See, for example, Bimson, Why Small Loans Cost More, in the February and March, 1945, issucs of Banking. Though oriented primarily in terms of consumer small loans, a number of the principles enunciated in these articles are appropriate to small commercial loans.

${ }^{103}$ Many banks have only the most hazy cost data to guide them in setting their lending policies. Certainly there is every reason for encouraging banks to determine their costs. On this point cf. Most Small Town Banks Never Study Costs, So $A B A$ to Do It for Them, Wall Strect Journal, September I, I944, pp. I and 6.
} 
torial comment on the appointment (on April I8, I945) of John W. Snyder as Federal Loan Administrator puts the matter, "he (Mr. Snyder) well knows that commercial banks cannot safely engage in certain types of lending, even though the need for loans may be pressing and opportunities for socially productive employment of borrowed funds may exist."104

Or one can claim that if, for example, the banks wished to modify their policies and embark on a large-scale program of term lending to small business on a constant-rate basis analagous to that of SWPC, they could do so on a profit-making basis. It is true that the attitude of bank examiners is sometimes cited as a restrictive influence on bank lending policies; but it seems questionable whether the examiners are the real stumbling block. Complete liquidity of bank funds is of course an impossibility; and the examining bodies realize that liquidity is (especially in view of FDIC deposit insurance) a false god except in terms of the long pull. Moreover, perusal of comments by bankers and banking groups brings to light very few complaints against the examiners. One can argue that the banking fraternity does not hesitate to criticize the actions of governmental bodies when it feels it has a grievance, and that it could very well do so in this instance if it believed it had a real case.

These considerations lead naturally to the following two-point program, here offered without direct supporting argument, as a means of promoting equal small business access to the credit and capital required for effective competition:

I. A federal loan-guarantee program (perhaps sponsored by RFC or Federal Reserve or separately by both) on a very large scale; ${ }^{105}$ or, if this proves inadequate or could fruitfully be complemented in "yard-stick" fashion, a large-scale program (perhaps developing from the wartime lending activities of Smaller War Plants Corporation) of direct federal loans.

2. Under proper safeguards, maximum encouragement and stimulation (including financial assistance from such federal agencies as Federal Reserve, RFC, and SWPC) of local, state, and regional private, quasi-public, and public industrial development groups as a source of long-term loan and equity capital.

${ }^{104}$ The Washington Post, April 19, 1945.

${ }^{105}$ Secretary of Commerce Henry A. Wallace has gone on record in favor of a program of Government guarantees for business loans made by private lending institutions. Wallace, Planning for Freedom, READER's Digest, May, 1945, pp. 3-4. Secretary Wallace also favors consideration of similar guarantees to assist small exporters (statement before Subcommittee on Foreign Trade for Small Business of the Senate Special Committee to Study Problems of American Small Business, April 17, 1945). The United Kingdom has had a self-supporting government operated system of export-credit guarantees since r921. In 1944 Canada enacted a law modeled after the British plan. 